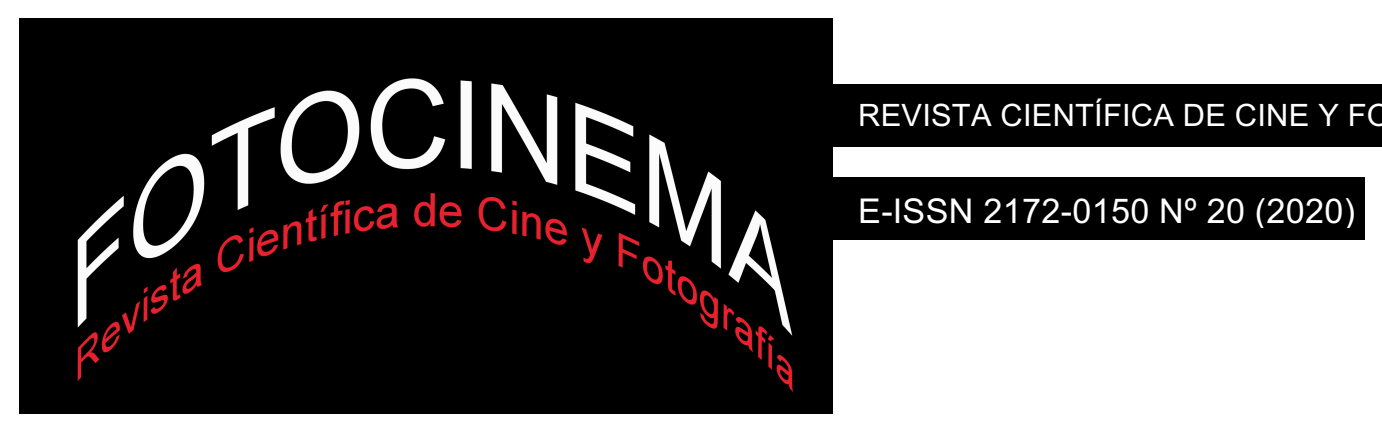

\title{
Otros modos de escribir la historia del cine: la cinematografía mexicana según tres documentales de los últimos años
}

\section{Other ways of writing cinema's history: Mexican cinematography according to three documentaries from the last years}

\author{
Silvana Flores \\ Universidad de Buenos Aires / CONICET, Argentina \\ https://orcid.org/o0oo-0003-0991-029X silvana.n.flores@hotmail.com
}

\section{Resumen}

Este artículo se propone analizar tres largometrajes documentales mexicanos lanzados en los últimos años que tienen en común su interés por forjar, a través del formato audiovisual, una memoria sobre la historia del cine de aquel país, y en torno a ello, sobre las microhistorias doméstico-familiares que involucran personalmente a sus realizadores, restituyendo ciertos aspectos sobre ese tópico en particular que incluyen tanto la reivindicación de la cultura popular como la proyección de experiencias privadas sobre dicha construcción. Aquellos films, Perdida (Viviana García Besné, 2009), La historia negra del cine mexicano (Andrés García Franco, 2016) y Bellas de noche (María José Cuevas, 2016), se destacaron por relatar algunas particularidades históricas del cine en contraste con lo que se ha tendido a llamar cine de arte o cine de autor, y vienen a recomponer y actualizar, por fuera de la disciplina historiográfica tradicional, aquellos fenómenos cinematográficos menospreciados por sus rasgos populares o, en ciertos casos, por su carácter controversial.

\begin{abstract}
This article proposes to analyze three Mexican documentary feature films launched in the last years, that have in common their interest to forge, through audiovisual format, a memory about the cinema's history of that country, and around it, about the domestic-familiar microhistories that involve personally to their directors, restoring certain aspects about that topic in particular, that include the reivindication of popular culture and the projection of private experiencies linked to that construction. Those films, Perdida (Viviana García Besné, 2009), La historia negra del cine mexicano (Andrés García Franco, 2016) and Bellas de noche (María José Cuevas, 2016), stood out for telling some historical particularities about cinema in contrast with the tendency of the called art cinema or author cinema, and they recompose and update, outside the traditional historiographic discipline, those cinematographical phenomena belittled because of their popular features or, in certain cases, because of their controversial character.
\end{abstract}

Palabras clave:

Documentales; México; historia del cine; memoria; cine popular

Key words:

Documentaries; Mexico, Cinema’s History; Memory; Popular Cinema 


\section{Introducción}

La historia del cine tiene como principal medio de elaboración y difusión a las publicaciones escritas, tanto las provenientes de los relatos plasmados en ámbitos periodísticos de diferente rango o especialidad, como aquellas gestadas a través de investigaciones vinculadas al ámbito académico-universitario. En el caso de América Latina, la revisión histórica sobre cine comenzaría a gestarse de forma sistemática en los años sesenta, desde un abordaje más asociado al ámbito periodístico y desde una perspectiva centrada en la idea de cine nacional, basada generalmente en un relato cronológico y sin prestar demasiada atención a la explicitación de las fuentes, aunque no por eso desprovista de una propuesta crítica y direccionada en torno a las preocupaciones de su tiempo. Así surgieron autores que propulsarían la disciplina como Domingo Di Núbila (1959, 1960) y José Agustín Mahieu (1966) en Argentina, Emilio García Riera (1963, 1969) y Jorge Ayala Blanco (1968) en México, así como Alex Viany (1959) en Brasil. La historia del cine se consolidó en un tono más academicista en torno a los años ochenta con una ampliación de los abordajes metodológicos y un mayor trabajo con fuentes, trayendo a la luz autores como Guy Hennebelle y Alfonso Gumucio Dagrón (1981), Peter Schumann (1987), Paulo Antonio Paranaguá (1985), John King (1994) y Zuzana M. Pick (1993), entre otros, que en base a los trabajos hechos previamente en torno a los cines nacionales, ampliaron el abordaje insertándose en la indagación sobre los cines regionales. ${ }^{1}$

Aun así, encontramos una vertiente alternativa, ya sea preparada para ser presentada en medios televisivos, informático-digitales o incluso fílmicos, que ha buscado levantar una (otra) memoria sobre la historia del cine a través de la realización de audiovisuales que narren su desarrollo o ciertos tópicos particulares por medio de la misma materia significante que conforma a la

\footnotetext{
${ }^{1}$ De acuerdo con los registros historiográficos que podemos verificar, los principales avances metodológicos que hubo en los últimos años, en particular en lo que respecta a las historias sobre cine latinoamericano, coincidieron con la aparición de trabajos volcados a búsquedas comparativas y transnacionales, así como a la elaboración de microhistorias, salidas mayormente de ámbitos científicos. Esto es evidente en principio en autores como los ya mencionados Schumann (1987) y Paranaguá (1985, 2000, 2003), pero se intensifica en las últimas décadas con las investigaciones de Elena (2005), Castro Ricalde y McKee Irwin (2011), López (2012), Serna (2014), Gunckel (2015), Moguillansky (2016), Lefere y Lie (2016), Lusnich, Aisemberg y Cuarterolo (2017), Gil Mariño y Miranda (2019) y Miranda y González Rivas (2019), entre muchos otros.
} 
cinematografía: las imágenes y los sonidos. En este artículo, analizaremos esta última tendencia, indagando un fenómeno de restitución de la memoria del cine mexicano que podemos observar de manera especial en los últimos años, abarcando tanto sus aspectos industriales como algunos temas o problemáticas de interés variados. Para ello, traeremos a la comparación tres documentales estrenados durante los últimos diez años, a saber: Perdida (Viviana García Besné, 2009), ${ }^{2}$ La historia negra del cine mexicano (Andrés García Franco, 2016)3 y Bellas de noche (María José Cuevas, 2016).4 Estos films se destacaron por relatar ciertos aspectos de la historia del cine de dicho país en contraste con lo que se ha tendido a llamar cine de arte o cine de autor. Aun reconociendo y estudiando la existencia de una tradición de cine popular mexicano propulsada por las rancheras y melodramas cabareteros durante el período clásico, o por la serie de films vinculados a la lucha libre en tiempos posteriores, por citar algunos ejemplos paradigmáticos, ciertos intelectuales especializados en el área, como es el caso de Emilio García Riera, miembro participante del periódico Nuevo Cine, junto a otras personalidades como José de la Colina, Salvador Elizondo y José María García Ascot, alentaron las novedades que ofrecía el cine de compromiso social emergente en los años sesenta y setenta, y vinieron a poner como foco de atención la crisis industrial a la que el cine mexicano había arribado con el desgaste del cine de género que durante años había puesto a dicha nación a la cabeza del mercado latinoamericano. Estas historias audiovisuales del cine mexicano vienen entonces a recomponer y actualizar por fuera de la disciplina tradicional, aquellos fenómenos cinematográficos que fueron menospreciados por sus rasgos populares o en ciertos casos por su

\footnotetext{
2 Perdida. Año: 2009. País: México/España. Duración: 96 minutos. Producción: Alistair Tremps. Dirección, guion y fotografía: Viviana García Besné. Música: Anahit Simonian. Sonido directo: Gabriela García Besné. Testimonios: Guillermo Calderón, Joaquín Cordero, Antonio de Hud, Rafael Inclán, Lyn May, Ricardo Montalbán, Sasha Montenegro, Aldo Monti, Ana Luisa Peluffo, Armando Silvestre.

3 La historia negra del cine mexicano. Año: 2016. País: México. Duración: 97 minutos. Producción: Centro Universitario de Estudios Cinematográficos. Dirección y guion: Andrés García Franco. Fotografía: Alfonso Mendoza G. Música: Sabino Alva Pulido. Sonido directo: Enrique Ojeda, Hugo Noriega. Testimonios: Jorge Ayala Blanco, José Felipe Coria, María Teresa Cortés, Federico Dávalos, Gustavo García, Sergio Guzmán, Lucio Ortigosa, Ana Rosas Mantecón. Intérpretes: Enrique Arreola, Marco García Franco.

4 Bellas de noche. Año: 2016. País: México. Duración: 92 minutos. Producción: Cine Pantera y Detalle Films. Dirección y guion: María José Cuevas. Fotografía: María José Cuevas, Mark Powell. Montaje: Ximena Cuevas. Música: Herminio Gutiérrez. Sonido: Lupita P. Kababié, Kiyoshi Osawa, Lía Pérez, Juan Sosa Rosell, Javier Umpierrez. Testimonios: Olga Breeskin, Lyn May, Rossy Mendoza, Wanda Seux, Princesa Yamal.
} 
carácter controversial, con la excepción de algunos estudios pormenorizados como los propiciados por el escritor Carlos Monsiváis (1996) en torno al melodrama o al cine de luchadores, o por el propio Ayala Blanco $(1968,1994)$ en relación con el cine de horror y también el de los enmascarados, así como los estudios referenciales acerca de la cultura de masas de Jesús Martín Barbero (1987), y yendo a tiempos más contemporáneos, con la reivindicación de los estudios vinculados a los dramas prostibularios propuestos por Cabañas Osorio (2014) o Vázquez Mantecón (2005).

Para abordar este fenómeno, tenemos en cuenta la concepción desarrollada por Robert A. Rosenstone (1997) quien examina el potencial del realizador cinematográfico para convertirse en una especie de historiador, contando la Historia (en este caso, la del cine) a través de otro tipo de documentos o materias expresivas. Más allá de las formas que el autor ha observado como frecuentes en el establecimiento de un vínculo interdisciplinar entre el cine y la historia -a saber, la historización del cine como actividad artístico-industrial y el uso de los films por parte de los historiadores como documentos para comprender aspectos socioculturales-, él se centra mayormente en un tercer enfoque, consistente en manifestar el modo en que el cine, como medio audiovisual en sí mismo, ha sido un objeto de reflexión sobre el pasado. El film pasaría a ser una forma de narración de la Historia comparable con lo que un historiador relata en el soporte lingüístico del ensayo histórico. De acuerdo con Rosenstone, la narración histórica escrita por un historiador puede considerarse una suerte de "ficción narrativa", a causa de su condición intrínseca de intentar "dar sentido al pasado" (1997, p. 36), en "una amalgama de datos unidos o ‘conducidos' por una visión o una teoría” (1997, p. 46). Asimismo, según el autor el cineasta puede constituirse en una especie de historiador o crítico. Los planteos de Rosenstone nos obligan también a reconocer los avances sobre las relaciones entre cine e historia desarrolladas previamente por Marc Ferro (1995), quien asume a los films como fuentes (por la información que podrían proporcionar sobre su tiempo) y como agentes históricos (en el sentido de que el cine en sí mismo ha tenido un lugar de relevancia en el desenvolvimiento de los progresos culturales y científicos y en la transformación de las sociedades, por ejemplo en cuanto a influir en modos de comportamiento o en ideología). Otros autores también remiten al poder de las imágenes para constituirse en 
documentos históricos, como es el caso de Peter Burke, quien considera, por ejemplo, que muchos pintores pueden ser considerados "historiadores de la sociedad alegando que sus imágenes registran formas de comportamiento social" (2005, p. 129), o establecen incluso con su arte un testimonio acerca de la vida política de su tiempo, permitiéndonos corroborar de ese modo las consideraciones de Rosenstone y Ferro en cuanto a las imágenes cinematográficas como testigos y agente de la Historia. Podríamos decir que cuando una película busca relatar eventos o períodos históricos determinados lo que sucede en realidad es también el establecimiento de una construcción cultural producto de la cosmovisión de quien la produce y/o dirige, y se establece entonces como documento.

En el caso de los films que aquí analizaremos, esta construcción de la Historia asume características metadiscursivas y autorreferenciales, ya que se pretende con ellos examinar aspectos propios de la historia del cine y de la historia personal de sus realizadores; con lo cual nos aproximamos a una perspectiva donde el relato histórico se mixtura continuamente con las vivencias individuales, emocionales y con los recuerdos subjetivos de quienes asumen la construcción narrativa y la enunciación del relato. Con el fin de entender esta dinámica, tomamos también en consideración la diferenciación entre historia y memoria establecida por Nora (2013), quien alude a la primera como una reconstrucción incompleta sobre el pasado, y considera a la segunda como la vida misma, "abierta a la dialéctica del recuerdo y de la amnesia inconsciente de sus deformaciones sucesivas [...] susceptible a largas latencias y repentinas revitalizaciones". Aun así, ambos conceptos se imbrican continuamente para su propia constitución. Otro autor que ha examinado la problemática de la memoria, define a esta como "representaciones colectivas del pasado, tal como se forjan en el presente" (Traverso, 2007, p. 69) que determinan de algún modo una forma de identificación social. A consecuencia de ello, estas películas no ofrecen una mirada objetiva sobre dicho pasado ni pretenden establecer una perspectiva unívoca y cronológica: los hechos se presentan como retazos de sus propias impresiones, como esa especie de recuerdo flotante que Nora adjudica a la memoria, y que además estructura, según Traverso, una determinada significación social que puede llegar a inculcarse a sus espectadores, receptores de esa representación. 
Por otra parte, estas películas tomarán la forma de microhistorias, debido a la inclusión de una visión de la historia general del cine mexicano partiendo de una escala reducida, es decir: estudiando un fenómeno más abarcador desde lugares particularizados, encuadrados como una muestra de esa historia general. Entendemos a la microhistoria tal como la define Levi (2018), en tanto perspectiva historiográfica que no se contrapone de forma tajante con la historia global, sino que, como su autor indica, busca "a través de un hecho, un lugar, un documento, un acontecimiento -leídos gracias a una ampliación de escala en un microscopio-, [...] identificar preguntas que tienen un valor general, pero que dan lugar a un amplio espectro de respuestas diferentes” (2018, p. 22). Así, los films relatan fenómenos singulares de algo más general, el desarrollo de la industria mexicana, y lo hacen a partir del desglose de áreas de la cinematografía poco abordadas como la trayectoria de una familia de cineastas, los Calderón; el estado de aquella industria a través de un fenómeno puntual que desató su crisis, como ha sido el monopolio de la exhibición en los años cincuenta; y las experiencias individuales y reflexiones sobre el espectáculo por parte de las ex vedettes del cine mexicano. Así, las películas que analizaremos se enfocan en agentes cinematográficos (exhibidores, distribuidores, productores, directores, guionistas, actrices, bailarinas) que, aunque no representan al cine mexicano en su "totalidad", sí nos impulsan a advertir fenómenos de relevancia en el desarrollo de dicha cinematografía.

\section{Historia de tres películas}

Los tres films arriba aludidos, coincidentes por provenir del registro del documental, tienen un origen particular basado mayormente en las experiencias individuales de sus correspondientes realizadores. Siguiendo un orden cronológico respecto al tiempo de su aparición, la primera película, Perdida, recorre la trayectoria cinematográfica de los Calderón, una familia de exhibidores, distribuidores y productores provenientes del norte de México y su influencia y posición respecto a diversos aspectos de la industria cinematográfica, a saber: la participación en la fundación de estudios 
cinematográficos, como fueron los Estudios Azteca, 5 la injerencia de algunas de sus transacciones y contactos para el progreso del cine sonoro, la exhibición y distribución del cine mexicano en el exterior o en el norte del país, y el debate sobre el cine popular y los formatos genéricos. Por otra parte, el film también se encarga de rescatar y preservar la memoria familiar, ya que su realizadora es, precisamente, bisnieta del fundador José U. Calderón, y sobrina nieta de sus hijos, los productores Pedro, José Luis y Guillermo Calderón. En efecto, la directora llevó adelante este film tras una investigación personal entre archivos personales y públicos, haciendo de sus antecesores los ejes de la narración. A ellos se suma el abuelo de la realizadora, el también productor Jorge García Besné, cuya historia de vida se dedicará a descubrir en el proceso, mientras despliega la trayectoria de estos agentes cinematográficos que las historias del cine no habían aún buscado recuperar. ${ }^{6}$

El segundo film, La historia negra del cine mexicano, retoma un aspecto puntual del desarrollo del cine de aquel país: las dificultades que vivió dicha cinematografía en torno a los años cincuenta con la monopolización del sector de la exhibición, y lo hace a través del recorrido por la trayectoria de vida y profesional del productor, realizador y actor Miguel Contreras Torres (18991981), proveniente de Michoacán. Un punto de conexión con Perdida es que su director también es descendiente del personaje sobre el cual discurre y, sumado a ello, aunque el documental de García Franco no haga referencia a los Calderón -más allá de la aparición de sus nombres en algunos afiches de películas-, el de Viviana García Besné sin embargo sí remite en una de sus secciones a la nombrada problemática del monopolio exhibidor, ya que había afectado notoriamente a sus antecesores en su calidad de dueños de salas. Por lo tanto, es factible establecer lazos entre las historias narradas en ambos documentales.

El fenómeno descrito en el segundo documental ha tenido una instancia de reflexión y agitación con la publicación en 1960 por parte de Contreras Torres

\footnotetext{
5 Los Estudios Azteca, localizados en Coyoacán (México D.F.) fueron fundados en 1938 por el ingeniero Gabriel García Moreno, siendo los ex trabajadores ferroviarios José y Rafael Calderón gerentes de dicha empresa. Tras la muerte temprana de García Moreno en 1943, estos se encargaron del área de inversiones.

${ }^{6}$ En la película también se otorga un lugar especial al testimonio de otros miembros de la familia que estuvieron vinculados oblicuamente con el mundo cinematográfico, como es el caso de la abuela de la realizadora y hermana de los productores Pedro, José Luis y Guillermo Calderón.
} 
de un escrito llamado El libro negro del cine mexicano, el cual inspira el título del film. En aquella publicación se pusieron en evidencia los negocios del magnate estadounidense William O. Jenkins (empresario vinculado, entre otras cosas, con el negocio del azúcar y la venta de alcohol) y sus socios Gabriel Alarcón y Manuel Espinosa Yglesias, para hacerse cargo, según dicen con métodos coercitivos, de las salas cinematográficas que formaban parte de la Compañía Operadora de Teatros (COTSA), las cuales estaban en manos privadas, generándose así un monopolio de la exhibición en el país.7 El autor del libro, tío bisabuelo de García Franco, buscó con aquella publicación manifestar su protesta ante este evento que habría perjudicado la exhibición de películas mexicanas.

Finalmente, el tercer documental revive las experiencias de las vedettes del cine mexicano que protagonizaron los films de ficheras entre las décadas del setenta y noventa, así como otro subgénero asociado conocido como las sexycomedias. A diferencia de los dos primeros títulos, la directora no proviene de ninguna familia cinematográfica, ${ }^{8}$ pero parte también de una investigación que, según sus propias declaraciones, ${ }^{9}$ le demandó alrededor de diez años de trabajo y surgió de su curiosidad acerca del involucramiento de una vedette del cine mexicano, la Princesa Yamal, en un célebre robo de piezas arqueológicas en el Museo de Antropología, tras el terremoto de Ciudad de México en 1985. ${ }^{10} \mathrm{El}$

\footnotetext{
${ }^{7}$ La problemática que rodea a la conformación de este monopolio tiene su inicio tiempo antes, con la implementación del célebre Plan de Reestructuración de la Industria Cinematográfica, o Plan Garduño, llamado así por ser promovido por Eduardo Garduño, a cargo del Banco Nacional Cinematográfico, buscando facilitar los vínculos entre productores y las distribuidoras dependientes del Banco. Dicho plan incluía también medidas proteccionistas para el cine mexicano, con un límite para la exhibición de películas provenientes de Estados Unidos, y buscó alentar la dupla calidad-rentabilidad, algo que no daría en definitiva los resultados esperados. Uno de los problemas que ese plan no supo prever fue el hecho de que el Banco otorgaba los créditos para las películas directamente a sus distribuidoras, siendo que muchos de los productores eran accionistas de aquellas empresas, generándose algunas irregularidades, entre ellas la inserción en aquel sistema del mismo Jenkins, dueño para ese entonces de gran parte de las salas de exhibición. Con el correr de los años el resultado de los esfuerzos del Plan Garduño implicó que aquel monopolio que tanto pretendió combatir terminara trasladándose a manos del Estado.

${ }^{8}$ Aun así, la familia de la cineasta está asociada con el ambiente artístico, ya que su padre, José Luis Cuevas, fue un conocido pintor mexicano. Por otro lado, su hermana Ximena también es realizadora y participó como editora del film.

9 Una de las fuentes que nos permitieron descubrir la génesis de este film es la entrevista en el programa televisivo español "Escala en París", que puede verse en el siguiente sitio: https://www.youtube.com/watch?v=ZhGPnAQX7yk

${ }^{10}$ La Princesa Yamal fue en ese entonces interrogada por la policía por poseer una pieza de joyería que le habría regalado su amante tras el robo. Aun no habiendo participado directamente de aquel delito, debió permanecer en prisión durante casi tres años.
} 
encuentro con la vedette, que será una de las protagonistas del film, despertó en la realizadora el interés por descubrir la persona que había detrás del personaje, y la de aquellas referentes del cine popular mexicano tras décadas de no ser más parte del mundo del espectáculo. Teniendo como disparador este episodio, Cuevas se dedica a transmitir el recuerdo de aquella etapa del cine mexicano signada por lo que se conoce en ciertos países como el destape, por la inclusión de desnudos en los films o de ciertas temáticas vinculadas a la sexualidad a consecuencia de la mayor permisividad de las instituciones reguladoras. Pero también, y principalmente, aprovecha aquella instancia para dar vía libre a la expresividad de sus entrevistadas, permitiéndoles que establezcan sus reflexiones particulares sobre variados aspectos de la vida. En cuanto a los puntos en común con los demás títulos, este documental también los tiene, ya que remite a un género cinematográfico ${ }^{11}$ que fuera lanzado primeramente por Guillermo Calderón a través de la película Bellas de noche (Las ficheras) (Miguel M. Delgado, 1975), la cual es el disparador para el nombre del film aquí referido.

Las tres películas tienen entonces varios puntos de interconexión, algunos manifestados de modo directo y otros que pueden inferirse al adentrarnos al universo por ellas desplegado. Pero el eje que las unirá más notoriamente es la vinculación entre la historia personal, por un lado, abordada desde las experiencias privadas de sus protagonistas, por medio de la cuestión del paso del tiempo, desde la idea del traspaso generacional o por la curiosidad que desatan sus respectivas investigaciones, y por el otro, la Historia de uno o varios aspectos de la cinematografía mexicana leída desde el tiempo presente.

\footnotetext{
${ }^{11}$ El cine de ficheras surge formalmente a mediados de la década del setenta, con el film aquí referido, consistiendo en películas cómicas con tendencia a la exhibición de desnudos, y que pronto derivaría en la variante de las sexycomedias. Sin embargo, su aparición no debe ser considerada un fenómeno fortuito, debido a que por su ambientación en cabarets, existen en estos films claras reminiscencias de una larga tradición de películas melodramáticas vinculadas a lo prostibulario, que se inicia con las dos primeras versiones cinematográficas de la novela de Federico Gamboa, Santa (1903) - la silente de 1918, dirigida por Luis G. Peredo, y la que dio comienzo al cine con sonido incorporado, realizada en 1931 por Antonio Moreno-, así como también a films como La mujer del puerto (Arcady Boytler, 1934) y el gran corpus del cine de rumberas que se desplegó entre los años cuarenta y cincuenta, y que tuvo entre sus promotores a los productores Calderón. A pesar de que Bellas de noche (Las ficheras) aparece en los registros históricos como iniciadora del género, puede considerarse un antecedente cercano a las temáticas presentadas en el cine de ficheras a una producción coetánea titulada Tívoli (Alberto Isaac, 1975).
} 


\section{Entre recuerdos e indagaciones: familia, industria y espectáculo}

\subsection{Conservar la propia memoria a través del cine: Perdida}

La película Perdida inicia con una conexión entre la memoria familiar de la realizadora Viviana García Besné12 y su propio descubrimiento y relación con el cine, mostrando unos rollos filmados por su bisabuelo, el mencionado exhibidor y distribuidor mexicano José U. Calderón. Aquellas imágenes encierran los recuerdos añejos de sus antepasados, con un objetivo particular: la restitución de una parte de la historia del cine mexicano que la historiografía tradicional ha decidido soslayar. Así lo anuncia García Besné, quien además es la voz narradora que guía el relato, afirmando que no había encontrado "ningún libro de cine mexicano que mencionara a mi bisabuelo, pero descubrí que en la historia del cine sí se hablaba de mis tíos abuelos [...] (de) lo malas que habían sido sus películas”. De ese modo, Perdida resulta una especie de lectura actualizada y revisionista sobre la cinematografía de aquel país, combinada con la búsqueda de una reconstrucción de la propia historia personal. El punto de partida se establece entonces en la dificultad de hacer coincidir los vagos recuerdos sobre la historia familiar y la escasa memoria cinematográfica que las crónicas han establecido respecto a las carreras de los Calderón. Ante dicho interrogante queda en evidencia la intención del documental de traer a la luz aquello "perdido" a lo que el título alude con el restablecimiento de una filmografía generalmente desplazada. Al mismo tiempo, lo perdido también remite a una reivindicación del cine popular por el que los Calderón fueron menospreciados, en donde hicieron desfilar, entre otros personajes, a las cabareteras, marginadas por la sociedad bajo el mote de "perdidas", ${ }^{13}$

\footnotetext{
12 Viviana García Besné es realizadora, guionista y editora, además de graduada en Comunicación Gráfica por la Universidad Nacional Autónoma de México (UNAM). Ha participado como editora en films como La pasión de María Elena (Mercedes Moncada Rodríguez, 2003), El inmortal (Mercedes Moncada Rodríguez, 2005), No hay lugar lejano (Michelle Ibaven, 2012) y Volando bajo (Beto Gómez, 2014), y como editora y guionista en El revés del tapiz de la locura (Maite Bermúdez, 2006). Perdida es su ópera prima como realizadora. Su trabajo en la práctica del cine se combina también con una comprometida labor en el área de la restauración y preservación de films en diversas instituciones, llegando a conformar su propio archivo cinematográfico y una sala de exhibición para la difusión de cine popular. Entre sus actuales proyectos se encuentra el documental en proceso Coleccionistas de sombras.

${ }_{13}$ De hecho, uno de los títulos producidos por los Calderón es un film del mismo nombre: Perdida (Fernando A. Rivero, 1950).
} 
"pecadoras" o "aventureras", del mismo modo que lo hicieron con ellos ciertos sectores de la crítica cinematográfica en sus requerimientos de "alta cultura".

Esta voluntad de contar historias y preservar recuerdos es guiada entonces por el interés de derribar los prejuicios estéticos sobre las producciones de corte popular salidas de las empresas productoras de Pedro, José Luis y Guillermo Calderón ${ }^{14}$ y responder a la omisión deliberada por parte del ámbito académico del carácter pionero de su padre en la actividad cinematográfica -y sus vínculos con Estados Unidos ${ }^{15}$.

Despojándose de la mera enumeración cronológica, el relato sobre el lugar ocupado por los Calderón en el cine mexicano se inicia con la etapa final de su trayectoria, es decir, con la invención por parte de Guillermo Calderón del cine de ficheras, género menospreciado por la crítica especializada por su manufactura narrativa y estética superficial, basada en albures, ${ }^{16}$ desnudos femeninos y el aprovechamiento de la música popular contemporánea. A partir de allí, se despliegan las diferentes dimensiones de las carreras de estos multifacéticos agentes cinematográficos, alternando el relato con el desarrollo de ciertos tópicos como la influencia de José U. Calderón en la industria mexicana y sus conexiones con Hollywood, los inicios de los negocios de la exhibición en la frontera de México-Estados Unidos, las actividades de distribución de cine mexicano en el país vecino con la empresa Azteca Films a partir del cine sonoro, y el comienzo del trabajo en la producción de los hijos de José a fines de los años treinta. A partir de este último suceso, el documental se abre a las múltiples maneras en que los productores se desenvolvieron para mantenerse firmes en la taquilla, en la atracción del público y en las polémicas, por medio de la contratación de célebres actores y músicos nacionales y

\footnotetext{
${ }^{14}$ Entre las empresas con las que lanzaron sus productos se encuentran principalmente Cinematográfica Calderón, S.A. y Producciones Calderón S.A., haciendo films que resultaron en melodramas cabareteros (también conocidos como cine de rumberas), películas de raigambre costumbrista y regional, como es el caso de su primera producción (La zandunga, Fernando de Fuentes, 1937), cine de terror y de luchadores, y finalmente, el más despreciado de los géneros en los que incursionaron: el cine de ficheras, junto a las sexycomedias.

${ }^{15}$ José U. Calderón, junto a su hermano Rafael, implementaron grandes avances en las zonas fronterizas entre México y Estados Unidos, tanto en lo que respecta a la distribución de films como en lo que concierne a la fundación de salas cinematográficas, generando un intercambio de características transnacionales en los tiempos iniciales de la industrialización del cine mexicano, y que perduraría por décadas. Para mayores detalles, ver Flores (2017; 2018a).

${ }^{16}$ El término "albur" remite a un juego verbal de doble sentido que se constituye en una suerte de duelo entre sus participantes, mayormente vinculado a la temática sexual.
} 
transnacionales, la incentivación de géneros que unieron música, historias melodramáticas y sensualidad (como sucedió con el cine de rumberas), y la producción de películas, durante los años cincuenta, asociadas a la juventud, el rock and roll y los desnudos, estimulando tanto los escándalos con la censura como la difusión al gran público, en tiempos donde las viejas fórmulas se estaban agotando. Aquellos cambios trajeron también intentos de inclusión de las nuevas tecnologías, como el $3 \mathrm{D}$, y la aparición de nuevos formatos y figuras del cine popular, destacándose el personaje de Santo, el enmascarado de plata, que protagonizó un buen número de films producidos por los Calderón y por Jorge García Besné. En relación con estas últimas películas, el documental da cuenta de un fenómeno de sumo interés, vinculado a las versiones dobles de las películas del Santo, que se definieron entre films para todo público y cortes con desnudos para exportación. Finalmente, se referencia también otro tipo de producciones de gran versatilidad, que rondan entre títulos de temática religiosa o infantil, y el cine de terror, que también contó, esta vez sin conocimiento de Guillermo Calderón, con versiones dobles (traducidas al inglés por productores estadounidenses). El documental incluye también la reflexión sobre la disyuntiva acerca del cine como un arte o una industria, entre las visiones encontradas de los productores privados y aquellos que aspiraban a realizar films de interés cultural, además de un resumen de la situación desventajosa que los Calderón vivieron durante el transcurso de la monopolización de las salas cinematográficas en los años cincuenta, referida de manera central en el documental de García Franco, asumiendo también un tono nostálgico en torno a la desaparición de los cines adquiridos por ellos inicialmente.

Frecuentemente se insertan aspectos colaterales vinculados al ámbito privado, como la truncada historia de amor entre la abuela de la realizadora y el actor Ricardo Montalbán, y su matrimonio con Jorge García Besné, así como también el breve romance entre José Luis Calderón y la actriz Emilia Guiu, y el enlace de Guillermo Calderón con la actriz Guillermina Green, razón por la cual esta última abandonaría su carrera. Con esto, se aprovecha la oportunidad para evidenciar la situación endeble de las mujeres en el ámbito cinematográfico en torno a la incompatibilidad entre el matrimonio, la maternidad y el estrellato. Pero será a través del relato de la historia de amor entre Pedro Calderón y la bailarina Ninón Sevilla, quien fuera la estrella más célebre en la filmografía de 
estos productores, donde el documental aporta las cuotas de cinefilia más potentes al espectador.

El desarrollo histórico que despliega el film es acompañado de un prolífico trabajo de edición de imágenes que interconectan las ideas a difundir, amalgamando fragmentos de películas, melodías representativas, los recorridos de la propia cineasta por espacios diversificados, y entrevistas a personalidades involucradas con la industria del cine mexicano, como los actores Ricardo Montalbán, Armando Silvestre, Antonio de Hud, Ana Luisa Peluffo, Joaquín Cordero, Aldo Monti, Sasha Montenegro, Rafael Inclán y Lyn May. Junto a ellos ofrecen sus testimonios, en esta especie de arqueología del cine mexicano, la representante de artistas Blanca Estela Limón, los historiadores Alma Montemayor, Fernando Muñoz C. y David Ramón, los periodistas Enrique Vidal y Mauricio Peña, y dos personas que aportaron datos sobre las salas regentadas por José U. Calderón: José Evangelista, uno de los empleados de la cadena de salas Alcázar, y John Salom, dueño del cine Colón. En medio de este desfile de entrevistados sobresalen los propios miembros de la familia de Viviana García Besné, en particular con el testimonio invaluable de Guillermo Calderón, el único de sus tíos abuelos productores que estaba vivo en aquel entonces, y el de su abuela Mate, la cual, a pesar de no estar involucrada centralmente en la industria fue, según la narradora, quien sembrara en ella "la curiosidad para poder conservar como tesoros las historias que había detrás de esos recuerdos”. Otros testimonios de familiares son los ofrecidos por Rafael Calderón Jr., cuyo padre participó junto a José U. Calderón de la fundación de salas y empresas distribuidoras, y por Memo Calderón Jr., hijo de Guillermo, que recuerda las contrataciones entre su padre y el Santo, así como la problemática de la estatización del cine y los reclamos por un cine de calidad. La entrevista será así uno de los recursos formales que más utilizará el film para aportar las informaciones correspondientes de acuerdo con la particularidad de cada entrevistado. Desde el testimonio de Guillermo Calderón como voz que ha protagonizado, y por lo tanto, ha vivido de primera mano los eventos evocados, pasando por los especialistas (historiadores que han sido partícipes de las indagaciones sobre el cine mexicano), los cuales dan sustento académico a estos trozos de relatos, así como también en el uso del anecdotario (ya sea por parte de personalidades de la industria o por miembros de la familia), que consolidan 
en sus diferentes funciones los testimonios que permitirán revisar la trayectoria de los Calderón.

La narradora hace su relato en primera persona, en una tendencia que Piedras ha observado en el documental argentino de las últimas décadas, que incluye la incorporación "del yo del cineasta en su entramado significante, como responsable y autor del discurso audiovisual" (2014, p. 21,22) y además como protagonista en el film. Aunque no podemos afirmar que el documental tenga tintes autobiográficos, sí se acerca a dicho género a través de una búsqueda identitaria, reforzada por un involucramiento personal, y un relato fragmentario (Di Tella, 2007). Este planteo de la narración histórica asociada a la biografía nos permite reflexionar sobre lo que Leonor Arfuch (2007) entendió como un fenómeno propio de la modernidad: el surgimiento del espacio biográfico como forma de conectar la individualidad con lo social, de imbricar lo privado con lo público. Pero no solamente este y los otros films conectan ambas esferas en la dialéctica entre la experiencia personal y la documentación de eventos o fenómenos históricos, sino que además se proponen como discursos dialógicos, en donde esa voz en primera persona se entremezcla con otros testimoniantes a los que cede también la voz en pos de la construcción de la memoria y de la puesta en relato de la historia. Retomando las ideas de Piedras, este film es un referente de esta vertiente del cine documental que busca convertirse "en vehículo [...] de la necesidad de los sujetos sociales de expresar y repensar sus identidades en el marco de los discursos de lo real” (2014, p. 21), proponiendo así una amalgama entre lo individual y su injerencia en lo social, o como bien expresa Catalina Sosa respecto a los archivos familiares: "la historia de uno podría ser en potencial [...] la historia de todos" (2017, p. 87).

García Besné también emprende el ingreso a lugares vedados por la familia (como la bodega de películas de Guillermo Calderón) y establece nexos entre aquella historia y la propia. Un ejemplo notorio de esto acontece en el primer tramo del film, cuando da cuenta del momento en que su bisabuelo y su hermano Rafael descubrieron el dispositivo cinematográfico, y al espectáculo al cual se dedicarían toda su vida. En esta instancia, se produce una asimilación entre dos iniciaciones: la de sus antepasados, seducidos por el nuevo aparato, y la de la misma realizadora, a quien se le empieza a revelar el hasta entonces 
oculto mundo en que su familia estuvo involucrada. Esa iniciación implicó descubrir los documentos y rollos de películas domésticas de su bisabuelo (que abrieron a un mundo desconocido respecto a su posición en la industria) y el conocimiento de una amplia y variada filmografía previa a la producción de las denostadas películas de ficheras.

Notamos así en este documental la referencia a dos aspectos vinculados a la investigación. Por un lado, el film está diagramado en base a la agrupación de información a través de diversas fuentes, la mayor parte de ellas tomadas de publicaciones periodísticas (entre las que se reconocen recortes de revistas como Cinema Reporter y Mundo Cinematográfico). Otras fuentes utilizadas son los propios archivos de la familia Calderón, que fueron localizados en diferentes lugares, como Chihuahua, Acapulco y en Estados Unidos, incluyendo también la visita a algunos de aquellos lugares para localizar testimonios y las reminiscencias de las salas cinematográficas que la familia administraba. Esos archivos domésticos, contextualizados con imágenes de ficheros, baúles, roperos, bodegas, salas de lectura y bibliotecas, son un conjunto de documentos de diferente naturaleza, tales como afiches de películas, cartas, registros de contabilidad, telegramas, expedientes, planos arquitectónicos de salas, agendas y álbumes de fotografías, fuentes que se complementan con las referidas entrevistas para reconstruir aquella historia poco indagada o más directamente marginalizada. Todos estos materiales son incorporados a la investigación audiovisual a través de una infinidad de recursos expresivos, que comprenden trucajes de fotografías y collages, además de fragmentos de algunas de las películas producidas por los Calderón, registros audiovisuales caseros, programas de televisión, y vistas de sitios de Internet, elementos concatenados con el fin de ilustrar las entrevistas y los comentarios en voz over de su directora. Este modo de referenciar la historia de su familia responde a un fenómeno alentado por la creciente digitalización provocada por las nuevas tecnologías y que abrazó también al cine en las últimas décadas. Así, como establece Eduardo Russo, ha surgido "un nuevo régimen de visibilidad" asociado a aspectos que García Besné ha sabido explotar a lo largo de su trayectoria, a saber, "los planos de la recuperación, conservación, circulación y fruición de los materiales cinematográficos" (2017, p. 58). El ambiente de investigación que el documental depara nos hace entonces testigos de los 
descubrimientos, planteando así una doble finalidad de recuperación de la memoria: por un lado, el cine pasa a ser una herramienta para reconstruir una historia familiar, y con ella quizás, la propia idiosincrasia, y por el otro, el film ofrece al espectador promedio de cine mexicano la oportunidad de descubrir al cine nacional.

Independientemente del memorial construido por Viviana García Besné, la película busca celebrar las posibilidades de ensueño que el cine ofrecía en los tiempos en que sus antecesores estuvieron activos y también actualmente, evidenciando la capacidad de reproducción de ese legado con el trabajo posterior que realizaría en diferentes áreas. En principio, con la creación en 2015 del archivo Permanencia Voluntaria, localizado en el pueblo de Tepoztlán (en el estado de Morelos), en el que reunió gran parte de la documentación hallada en el país y el exterior a propósito de la consecución de su film, así como también algunos rollos de películas. Y luego, con la creación de una sala de exhibición en aquel mismo lugar, llamada Baticine, en donde se organizan proyecciones tanto de colecciones de films de los Calderón como de cine popular mexicano en general, tomando en ocasiones la forma de cine ambulante. ${ }^{17} \mathrm{El}$ film culmina trazando una línea sucesoria desde los antepasados hacia el pequeño hijo de la realizadora, jugando frente a una pantalla en la que fluyen las imágenes de la familia, sumándose así a la idea de continuidad que implicaron las referidas actividades de conservación y exhibición.

\subsection{Del libro a la pantalla: La historia negra del cine mexicano}

En el caso de La historia negra del cine mexicano identificamos también un vínculo con el ámbito de la investigación o, mejor dicho, la película surge de una referencia bibliográfica, aunque no académica, en torno a los fenómenos industriales de la cinematografía mexicana. Dicho material comprende el escrito ya mencionado de Contreras Torres que denunció, como ya adelantamos, la formación de un monopolio en el área de la exhibición que habría ido en detrimento de la industria cinematográfica. Por otra parte, del mismo modo que Perdida, el film se inicia con una experiencia personal y el uso de la primera

\footnotetext{
${ }^{17}$ Para mayores referencias sobre el funcionamiento de estos espacios, léase una entrevista a la propia realizadora (en Flores, 2018b) y el siguiente sitio web, donde se encuentra información oficial al respecto: $\underline{w w w . p e r m a n e n c i a v o l u n t a r i a . i n f o}$
} 
persona por parte de su realizador, ${ }^{18}$ constituyéndose en narrador al igual que García Besné. El director parte entonces de sus impresiones infantiles, recordando el momento en que se topó con aquel polémico libro en la biblioteca de su casa. Esa misma impresión es retomada al relatar su ingreso a la Universidad, en donde volvería a escuchar en boca de sus profesores los acontecimientos narrados por su antecesor ${ }^{19}$.

Esta película contiene numerosas similitudes con Perdida, que había abierto siete años antes el camino a este tipo de enfoque, basado en la reconstrucción audiovisual de la historia cinematográfica enlazada con los retazos de la memoria familiar. Por tanto, La historia negra del cine mexicano también tomará como referencia ciertos aspectos formales del anterior film, a saber: el empleo de archivos concernientes a artículos de revistas cinematográficas, la utilización de la música como un acompañamiento que evoca tiempos pasados, así como fragmentos de las películas, animaciones y trucajes con fotografías, entrevistas a diferentes personalidades tanto del ámbito público como privado, y finalmente, imágenes de rollos de films mostrando las anotaciones de sus títulos, los cuales aparecen en diferentes ocasiones llamando la atención en los pasillos de las instituciones visitadas por el realizador. Con excepción de algunas reconstrucciones ficcionales que proporciona como elemento distintivo el documental de García Franco, otro aspecto común con Perdida es la inclusión de ciertas ilustraciones de los conceptos vertidos en su relato con la exhibición de fragmentos de los films de Contreras Torres, así como también de los documentos epistolares, y de la filmación de edificios vinculados al mundo del cine en su actualidad. Incluso, al igual que en Perdida, el director relata sus sueños nocturnos provocados por la inquietud que su investigación parece generarle, marcando así una influencia o una sintonía entre los aspectos

\footnotetext{
18 Andrés García Franco es director cinematográfico graduado del Centro Universitario de Estudios Cinematográficos (CUEC-UNAM), además de poseer una Maestría en Estudios Visuales y Cine del San Francisco Art Institute. Su ópera prima, La historia negra del cine mexicano, obtuvo el apoyo para su producción de la Filmoteca de la UNAM y el Concurso de Ópera Prima Documental del CUEC (2012). Entre su filmografía se conoce el cortometraje ficcional La invención de Morel (2009) y el cine-ensayo Cines abandonados (2009). También trabajó como editor en films como El otro Diego (Rubén Montiel Mendoza, 2007) y en el episodio Toscanito, coleccionista de historias (Gregorio Carlos Rocha Valverde, 2010), del film Luces, cámara, irevolución!, encargado de documental la forma en que el cine ha representado los eventos de la Revolución Mexicana y la labor del pionero del cine Salvador Toscano.

${ }^{19}$ Entre ellos puede verse la grabación del fragmento de una clase de José Felipe Coria que, por otra parte, integra el plantel del film como productor, reforzándose así el carácter de investigación que reviste a este documental.
} 
históricos en los que Contreras Torres estuvo involucrado y las impresiones personales de García Franco.

El narrador hace también referencia a las diferentes visiones que su tío bisabuelo generó en el ámbito cinematográfico, no solo registrando las exposiciones de clases de cine recibidas en el Centro Universitario de Estudios Cinematográficos (CUEC), donde García Franco estudió, sino también rescatando los archivos de la TV UNAM, donde se observa la opinión del célebre escritor Carlos Monsiváis acerca de Contreras Torres, expresando claramente sus reparos sobre la calidad artística de los films del realizador y a su vez una valorización de sus denuncias contra Jenkins, atribuyéndole con eso un acto de valentía. Asimismo, también se exhiben algunas reflexiones salidas de un texto de la investigadora Juana María Perujo sobre su filmografía, y las palabras grabadas sobre una entrevista transcrita a la esposa de Contreras Torres, la actriz Medea de Novara, ${ }^{20}$ la cual se dedica a dar cuenta de su amor por México a pesar de su extranjería, añadiendo así al perfil del retratado los aspectos vinculados a su ámbito privado.

El listado de entrevistados en este film es extenso, y esto se debe mayormente al gran número de familiares cercanos y lejanos a los que García Franco toma testimonio. Estos son Amalia Franco Contreras, madre del director y sobrina nieta de Miguel Contreras Torres, y Rolando García Gaytán, su propio padre. Por otra parte, entrevista a Elías Eduardo Contreras Cordero, su primo, y un gran número de sus tías (Licha, Concha Contreras Meléndez, Rosy Contreras M., Dulce María de Contreras y Blanca Contreras Meléndez), además de su tío David Contreras. Por fuera del ámbito familiar, se recopilan relatos de la investigadora de cine de Michoacán, María Teresa Cortés, de Teresa Bonilla, presentada como académica en Ciencias Económicas de la BUAP, del presidente de la Sociedad de Directores Víctor Ugalde, de los investigadores de cine Federico Dávalos, Jorge Ayala Blanco y Ana Rosas Mantecón, de los historiadores de cine José Felipe Coria y Eduardo de la Vega, de los críticos

\footnotetext{
20 Medea de Novara nació en Liechtenstein con el nombre de Hermine Kindle Flutcher, y se desempeñó como actriz durante las décadas del treinta y cuarenta, ya sea en films mexicanos como estadounidenses. Había conocido a Contreras Torres en Hollywood, y desde ese entonces fue parte de varias películas dirigidas por aquel, interpretando por ejemplo a personajes como la emperatriz Carlota y María Magdalena. En el fragmento sobre esta relación, también se graban palabras testimoniales del programador de cine Lucio Ortigosa.
} 
cinematográficos Gustavo García y Naief Yehya, del ingeniero Alberto Jiménez, que da cuenta del lugar que ocupara Jenkins en sus comienzos como industrial del azúcar, del Dr. Sergio Guzmán Ramos, amigo de la familia Jenkins, de Pilar Elías, empleada del Centro de Convenciones Puebla William O. Jenkins (cuyo testimonio se utiliza para dar chance a la expresión de la versión positiva sobre el magnate en dicho lugar), de Francisco Gaytán (encargado de la preservación de los acervos fílmicos de la Filmoteca de la UNAM, del que solamente se toman imágenes), del anticuario y director de arte Enrique Estévez, quien participara de algunas de sus películas, de Lucio Ortigosa, presentado como programador del cine Nostalgia, del lingüista Rubén Bonifaz Nuño, de Celeste North, una de las fundadoras de la plataforma web Nuflick, en torno a los desafíos de la exhibición en el siglo XXI, y del analista de mercados Ernesto Piedras. Todas estas voces, que dialogan con el desfile de fotos fijas y con unas pocas escenas ficcionalizadas, confluyen para el establecimiento de las diferentes líneas que el film utiliza para implantar testigos sobre la problemática tratada. Estas consisten, al igual que en el documental Perdida, de voces de autoridad asociadas al mundo académico y de la reflexión sobre el cine, así como también las de aquellas que pertenecen al ámbito privado-familiar de Contreras Torres y García Franco. Todas asumen el discurso contra los efectos del monopolio de Jenkins, aunque el realizador haría lugar, en una mínima escala, a testimonios que validan el rol del empresario Jenkins en la industria mexicana.

El film está estructurado en capítulos, previa presentación del realizador para ubicar al espectador en la temática a tratar. El primero de ellos, titulado "La vida inútil del tío Miguel”, en alusión a una de las películas de Contreras Torres, La vida inútil de Pito Pérez (1943),21 aborda su carácter de pionero para la cinematografía mexicana, relatando también su paso por el Ejército en las filas del general carrancista Elizondo, en donde cumpliría funciones como camarógrafo. El segundo capítulo se titula "Meet Mr. Jenkins" y versa sobre la figura del empresario que se constituiría en dueño de todos los cines de México, formando lo que se conoce como el "monopolio Jenkins de la exhibición”. Este episodio está elaborado en un tono irónico, emulando en ciertos tramos el estilo

\footnotetext{
${ }^{21}$ A lo largo del documental, la asimilación entre el personaje de Pito Pérez en aquel film y la figura de Miguel Contreras Torres será constante, utilizándose escenas de la película para dar inicio a la biografía del realizador y también para relatar su muerte.
} 
de los noticiarios y utilizándose en ocasiones una voz narradora over en inglés, a tono con la acaparación del industrial. El tercer capítulo se llama "Loco y vagabundo”, ${ }^{22}$ y aborda el carácter multifacético de Contreras Torres en su rol de actor, distribuidor, productor y actor, entre otros aspectos, además de su participación en el cine de Estados Unidos y España, su matrimonio con Medea de Novara, y la llegada del cine sonoro, siempre manteniendo a lo largo del relato la sombra de William O. Jenkins, aludiendo a él por medio de analogías ilustradas con fragmentos de una película de aventuras. Continúa el film con el capítulo 4, titulado "Rancho de mis recuerdos" (también en alusión a una de las películas dirigidas por Contreras Torres en 1944), en donde se hace referencia a los espacios privados en el hogar de Contreras Torres, contraponiéndolo luego con un breve recorrido de los espacios públicos del cine, específicamente los diferentes estudios cinematográficos en donde se desplegó el cine mexicano durante el tiempo de actividad de este cineasta. En el capítulo 5, "Hombre o demonio",23 siguiendo la línea del tópico del monopolio de la exhibición, encontramos una de las recreaciones ficcionales que ofrece el film, relatando los negociados de William Jenkins para comprar el cine Guerrero de la ciudad de Puebla tras el misterioso asesinato de su dueño. En conexión con esto, el capítulo 6, llamado "El último rebelde", ${ }^{24}$ aborda la confrontación del propio Contreras Torres hacia Jenkins, tras la publicación en los medios de una carta en la que lo acusa de crear dicho monopolio y afectar así la industria nacional. Allí también se observa que Contreras Torres no estaba solo en su denuncia, ya que hubo más agentes, como el escritor José Revueltas, que se atrevieron a hacer lo mismo 25 . El documental testifica que la batalla emprendida por Contreras Torres provocaría su progresiva marginación de la industria, obteniendo pocos créditos, y llevándole a dedicarse a otras actividades. En ese interín, se deja traslucir también el deterioro de la calidad de las producciones a consecuencia de las nuevas ordenanzas salidas tras la promulgación de la ley Garduño, que si bien buscaba un despuntar de la producción, provocaría sin embargo el efecto contrario: el "enlatamiento" de películas, un fuerte accionar

\footnotetext{
22 En 1945, Contreras Torres produjo un film que lleva aquel título.

23 Este es el nombre de un film dirigido por Contreras Torres en 1940.

24 El título de este capítulo vuelve a hacer referencia a un film de Contreras Torres del mismo nombre, dirigido en 1958.

25 Puede encontrarse el texto sobre esta cuestión lanzado por aquel escritor en 1949 en Revueltas (1981).
} 
sindical, las dificultades en los costos de producción y, en consecuencia, un encarecimiento de las cualidades estético-narrativas. Además aborda la nacionalización de la industria cinematográfica a partir de la década del sesenta, que sería el paso posterior al monopolio exhibidor, haciéndose una reflexión en torno a la corrupción que aquello generaría a posteriori y a la lucha entre los productores privados y los financiados por el Estado. El siguiente tramo, bajo el nombre "Amor a la vida", aborda los aspectos concernientes a los últimos días y la muerte de Contreras Torres, y reflexiones sobre su legado y los ciclos de la vida, en donde intervienen los factores personales del propio realizador, García Franco. Allí también el cineasta reflexiona sobre las vicisitudes de la exhibición del cine y las legislaciones en el tiempo presente, así como reivindica la cultura nacional, haciendo una línea de continuidad respecto a la temática por la cual su tío bisabuelo también habría luchado décadas antes. Finalmente, el epílogo se corresponde con los créditos finales, en donde quedan asentadas mayormente las fuentes de documentación que fueron utilizadas en el proyecto audiovisual, acompañadas de imágenes de antiguas salas cinematográficas y edificios variados de su país, en un tono de deliberada nostalgia construido por medio de una melodía de ritmo pausado y melancólico.

Tanto el film de García Besné como el de García Franco buscan bucear la memoria cinematográfica con el fin de reivindicar a sus familiares como pioneros poco valorados o incomprendidos en la industria, y al mismo tiempo, en el trabajo de conexión con su propia historia personal, proyectan la línea generacional por ellos suscitada. En el primer caso, reconstruyendo la trayectoria de José U. Calderón, sus hijos productores y el propio abuelo de la directora; en el segundo, por medio de las constantes intervenciones de sus familiares, que si bien no están involucrados con el mundo del cine, sí tienen varios elementos para aportar respecto de la personalidad de Contreras Torres. Esa línea sucesoria llega a los propios realizadores, pero también, en ambos casos, les trasciende. Esto último es establecido a partir de la inclusión en los films de un tópico común, los ciclos de vida, que es ilustrado a través imágenes de sus propios hijos pequeños como un emblema de los dos extremos de esa 
memoria familiar testificada por el cine. ${ }^{26}$ En lo que respecta a esta extensión, ambos films muestran un potencial de establecer continuaciones en la labor en base a una serie de emprendimientos o reflexiones plasmadas: ya sea a través de las actividades generadas por Viviana García Besné con la creación de su archivo y sala de cine, como por la proyección realizada por García Franco respecto a lo que sucederá en el mundo de la exhibición de films con el surgimiento de las nuevas tecnologías.

\subsection{La vida después del cabaret: Bellas de noche}

El tercer documental, Bellas de noche, tiene una estructura diferente ya que se centra en un solo fenómeno, el del mundo de las vedettes que circularon por el cine mexicano a partir de los años setenta; y también debido a que está despojado de la estructura enunciativa en primera persona, aunque sí posee como los otros un matiz de reflexividad, en este caso en torno a la vida de las cinco mujeres a las cuales María José Cuevas 27 entrevista y filma (Lyn May, Olga Breeskin, Princesa Yamal, Rossy Mendoza y Wanda Seux). Por otra parte, al igual que las otras dos películas, el tono nostálgico permanece también aquí desde el propio inicio, en donde se despliegan imágenes de una de aquellas populares vedettes, Lyn May, en un número musical de antaño, donde se contornea sensualmente para su público. A continuación, también se da a conocer una vieja entrevista, que sirve de punto de partida para reflexionar acerca de qué significa la profesión de las bellas nocturnas aludidas en el título del documental.

Los créditos iniciales están basados exclusivamente en la presentación de las vedettes, que rondan entre los sesenta y los setenta años de edad. Musicalmente

\footnotetext{
${ }^{26}$ En el caso de García Franco, el ciclo de la vida se ejemplifica también con la información, primero proporcionada por su madre y luego reiterada por él mismo, de que su nacimiento se produjo en el año en que muriera Contreras Torres, específicamente tres meses después. Algo similar sucedería con su propio hijo, de quien afirma que estaba en gestación en el tiempo en que su abuela falleció. Por su parte, García Besné dedica el tramo final de su película a homenajear a sus entrevistados "que se fueron en el camino", y en especial a su abuela, de quien considera que siempre formará parte de ella, así como "de los que vengan".

27 María José Cuevas es directora cinematográfica, además de Diseñadora Gráfica por la Universidad Iberoamericana (UIA). Entre sus films se encuentran un buen número de cortometrajes, como Eventos sociales, Platónicos infantiles, Lunch with daddy y Mal de amores, todos realizados en el 2005, así como Remake (2006) y Heal the world (2009). Bellas de noche es su primer largometraje, siendo premiado en diversos festivales. Entre sus actuales proyectos se encuentra un documental en coproducción con su hermana Ximena Cuevas, vinculado a la temática de la manipulación e inspirado en un episodio de la vida de su padre, el pintor José Luis Cuevas.
} 
están acompañados de la canción que forma parte de los créditos del film de 1975 Bellas de noche (Las ficheras), con el cual, a su vez, Viviana García Besné comienza el recuento de la trayectoria de sus tíos abuelos en Perdida. Las vedettes son introducidas al público con la imagen que tenían cuando eran jóvenes, hasta llegar a la primera en ser entrevistada, quien ya transcurridos los años se viste nuevamente con sus plumas y penachos delante de la cámara, esta vez ya no en el escenario sino en el ámbito privado.

Es ese espacio alejado de los reflectores de los teatros el que este film va a recorrer, sumando reflexiones sobre variados temas que la directora fue captando a lo largo de su convivencia con las protagonistas del documental. Uno de los tópicos más sobresalientes aquí tratados es la idea de la belleza, valor históricamente ensalzado por el sistema de estrellas del cine industrial (Morin, 1964), junto con la juventud y el sex appeal, así como la inevitable fugacidad que se corresponde con el paso del tiempo. En el primer tramo, Rossy Mendoza, erigida en esta instancia como voz representante de sus colegas, señala lo siguiente: "somos mujeres hermosas... que manejamos la belleza como parte de nuestro espectáculo". Pareciera que el punto común de sus declaraciones fuera la lucha por la permanencia de aquel valor a lo largo de los años, aun cuando las arrugas o los efectos causados por las cirugías estéticas sean notoriamente visibles. Las figuras deseadas e intocables se tornan cercanas ahora, permitiendo al espectador ingresar a su mundo interno. Esa belleza va a ser mostrada emplazando a las ex vedettes en espacios cotidianos de su tiempo presente, ya sea sus propios hogares, salones de belleza, o lugares abiertos como parques. Si algo podemos notar a lo largo del film es que el retiro de la profesión y los efectos de los años en el cuerpo no implican en estas mujeres un retiro de la vocación por la danza y el exhibicionismo, valor que ponen en primer plano, en un deseo de crear y sostener sus imágenes como seres especiales y exclusivos. Ese interés por extender su vocación más allá de la carrera profesional es remarcado continuamente en el documental, mostrando a las propias ex vedettes haciendo sus números musicales para la cámara en el interior de sus hogares.

En esa misma dirección, otro tópico sobre el cual indaga Bellas de noche es el mundo del espectáculo y su efecto de retroalimentación con el público, el cual 
disfruta el acto de mirar mientras las vedettes gozan a su vez con el hecho de ser miradas. Esto es evidenciado en una entrevista a Lyn May en sus años juveniles, en la que expresa un deseo de "enseñar" su cuerpo, entendido por ella como una marca de nacimiento, es decir, como algo inherente a su persona. También afirma su intención de nunca dejar de practicar el strip-tease mientras tenga la posibilidad de mostrar su cuerpo. Ese deseo coincide en las declaraciones de cada una de ellas, como por ejemplo en el caso de la Princesa Yamal, que afirma siempre haber querido ser especial, adquiriendo una personalidad asociada a lo exótico, en su caso en relación con la cultura árabe y la idea de realeza (reafirmada en su nombre artístico). Esta es una cuestión sobre la cual las entrevistadas emitirán continuamente sus opiniones, es decir, la representación de la figura de la vedette como algo más que una mujer de bella contextura física, sino más bien como alguien que se erige como una especie de diosa profana de los escenarios. En sus declaraciones, las ex vedettes también se sinceran respecto a la existencia de un efecto contrario de su pregnancia en los públicos, que deriva en los excesos de alcohol y drogas, la depresión y la soledad.

Por otra parte, el desnudo será una de las cuestiones que las protagonistas del documental también mencionarán, planteando los tabúes respecto al acto de mostración del cuerpo, algo en lo que todas han incursionado tanto en el cine como en sus presentaciones en vivo. Ellas plantean su afición por mirarse a sí mismas en las viejas representaciones, como sucede con Rossy Mendoza, que observa los videos por Internet de las películas en las que formará parte. Junto a esto se aborda además el binomio pasado/presente, en donde se hace notar el paso de los años y un efecto de comparación asociado a las nociones de juventud y vejez. La forma en que esto se manifiesta es a través del contraste entre las vedettes en el día de hoy ante los registros audiovisuales de sus antiguas representaciones, con un subsecuente efecto de extrañamiento en el espectador al observar a estas mujeres sexagenarias usando vestimentas sensuales como en los tiempos pasados. También se hace mediante la exhibición del proceso de embellecimiento a través del maquillaje o de tratamientos faciales y corporales, así como de las rutinas de ejercicios, las reflexiones frente al espejo o la exhibición de pinturas (como las que tienen Rossy Mendoza y Princesa Yamal en las paredes de su casa) que eternizan sus figuras juveniles. En los 
comentarios de las artistas, la cuestión de la autoestima y la afirmación del valor propio es un denominador común, reforzando la denominación de "reinas", “diosas” o "estrellas”. Así, la Princesa Yamal admite los cambios traídos por el tiempo, pero se consuela diciendo que "la piel envejece, pero el alma no".

Otro punto de interés es el emplazamiento de las vedettes ya retiradas en espacios que no se corresponden con el imaginario construido acerca de ellas, específicamente el club nocturno o los escenarios de cabaret de las películas donde se presentaron. Vemos entonces a Lyn May ejercitándose en un parque y dando consejos sobre la seducción y el placer a su entrevistadora, o a Rossy Mendoza haciendo un número musical en su cocina o en su living, a Wanda Seux cantando en un viaje en auto o cuidando diligentemente a sus perros, y a la Princesa Yamal amasando y cocinando. El glamour se combina con la cotidianeidad, mostrando el juego de transformaciones que dicha profesión implica, pero también exponiendo las nuevas ocupaciones de estas mujeres, que rondan entre la militancia por la causa de los animales, la metafísica y la fe. También se hace referencia a los aspectos sentimentales de su historia pasada o presente, y todas recuerdan sus experiencias de crisis personal, desde el involucramiento de la Princesa Yamal en el referido robo, pasando por la enfermedad oncológica que atraviesa Wanda Seux, hasta el relato sobre un extraño proceso de duelo de Lyn May tras la muerte de uno de sus maridos.

Finalmente, la película también tiene sus momentos de autorreferencialidad, no solamente por las entrevistas frontales, que inevitablemente aluden al dispositivo cinematográfico, sino también por la intervención de la realizadora, María José Cuevas, en diferentes instancias del film, generando un juego de saberes y de intercambio de roles en el control de lo que se expresará en la relación diádica entre entrevistadora y entrevistadas. En primer lugar, la voz de la realizadora es oída haciendo preguntas fuera de cuadro; luego, las entrevistadas, como sucede con Lyn May en su diálogo en el parque, involucran a la entrevistadora con preguntas personales hacia ella. También vemos a la Princesa Yamal hablando por teléfono con Wanda Seux, no sin antes comentarle que está filmando con María José, evidenciándose así no solamente la situación enunciativa sino también mostrando que la entrevistada también puede tener por momentos una función más activa en la relación. En la serie de 
intercambios con las artistas, podemos notar otra de las características distintivas de la entrevista, descrita por Arfuch como la "mostración pública de la afectividad" (2007, p. 154), que procura la ampliación del conocimiento sobre el sujeto entrevistado desde un lugar de mayor proximidad. La presencia de Cuevas en los momentos en que las vedettes abren paso a su espacio íntimo se encuentra latente, pero aludida en los intercambios, tal vez por la confianza adquirida a lo largo de la convivencia que dio pie a la realización del documental. Por último, la propia realizadora, en una práctica muy propia de lo que Nichols (1997) llamara documental interactivo, es quien acompaña a Wanda a dar la inyección letal a una de sus mascotas enfermas, haciéndose partícipe de aquel momento privado. De ese modo, el mundo representado en el documental se entremezcla con el de la cineasta, en una suerte de vínculo comunicativo en donde también interviene el espectador, completando el triángulo como testigo. Aun así, el nivel de involucramiento de María José Cuevas, que siempre es referida en un fuera de campo y que trajo a la luz este film tras un contacto continuo de muchos años con las ex vedettes, pasa más desapercibido que el de los otros dos realizadores, para quienes el mundo referido en el documental de algún modo forma parte constituyente de su propia identidad y de la memoria borrosa sobre sus antecesores que ellos intentan reconstruir y reivindicar.

\section{Conclusiones}

A lo largo de las anteriores páginas hemos buscado establecer una serie de conexiones entre los tres films estudiados que nos permiten entender otras formas de relatar la historia de la cinematografía mexicana, teniendo en cuenta factores que aluden a memorias domésticas y a cierta reivindicación de fenómenos culturales menospreciados por la historiografía tradicional por no ser parte del llamado cine autoral o cine de arte. De ese modo, descubrimos que el desarrollo histórico del cine mexicano se dio también a partir de las experiencias de ciertos individuos poco estudiados y que estos films pretenden acercar a un foco de visibilidad mayor.

También nos hace reconocer una vez más que el cine, y en este caso el documental, puede ser una herramienta de reflexión sobre aspectos tanto 
colectivos como individuales, logrando en los títulos analizados que ambos aspectos confluyan en uno. Los tópicos abordados nos llevan no solamente a fortalecer este vínculo entre la historia general y las microhistorias domésticas, sino también a establecer una extensión de ciertas problemáticas aludidas al tiempo presente, demostrando que la historia no se circunscribe a la recapitulación del pasado, sino que posee injerencias para la reflexión sobre el día de hoy.

Por otra parte, nos ofrecen una perspectiva historiográfica basada en el formato audiovisual, el cual se constituye en un digno instrumento para el estudio de dicha materia. Los tres films revelan una vez más el estatus del cineasta como historiador -en estos casos involucrados personalmente con aquella Historia que buscan documentar-, y suscriben a la inclusión del arte cinematográfico como agente para indagar la historia y la cultura a través de la utilización del registro documental como forma testimonial usualmente validada en el ámbito del cine, así como también por su empleo de archivos y su intención de extender las reflexiones al campo actual. $\mathrm{Y}$ en lo que respecta al uso de documentaciones periodísticas y filmográficas, o de materiales domésticos encontrados y proporcionados por los propios realizadores, los films recalcan su uso como un modo de traer a la luz aquellas historias que buscan rescatar, con el fin de que, tal como proclama Foster, "la información histórica, a menudo perdida o desplazada, esté físicamente presente" (2016, p. 103). Serían fuentes, según el autor, que pueden funcionar como una especie de memoria alternativa, que viene a recuperar determinado conocimiento. Los realizadores incluyen dichos archivos en los films en un fluido intercambio con las entrevistas y el relato de la voz narradora principal, viniendo a enfatizar dichas expresiones, a simplemente ilustrarlas, buscando revivir las figuras de quienes ya no están -transformando al archivo como un soporte de la memoria (Sosa, 2017)-, o con menor frecuencia, estableciendo un contrapunto orientado a la explicitación de ironías. En la mixtura entre esas imágenes y sonidos rescatados del pasado con los elementos del presente (representados mayormente en las entrevistas o en los episodios ficcionales del film de García Franco) estas películas establecen un diálogo de compatibilidad en su diversidad de significantes y temporalidades. 
Perdida revisa la historia general del cine mexicano por medio de trayectorias cinematográficas particulares (las de los integrantes de la familia Calderón/García Besné) que abren un abanico de opciones para más estudios académicos en torno a las áreas de la distribución, exhibición y producción. Es así como el texto cinematográfico, elaborado en base al concepto de historia audiovisual, abre paso a la conformación de textos historiográficos escritos que pueden servirse del primero como fuente para la indagación. En el caso de La historia negra del cine mexicano observamos también esa correlación: la publicación de Contreras Torres pasa a ser tratada en el audiovisual por medio de una estructura narrativa segmentada en capítulos, como una especie de libro hecho con imágenes y sonidos que aluden tanto a la filmografía del realizador como a los planteos sociohistóricos que del libro impreso se desprenden. Podemos vislumbrar también un interés no solamente por reincorporar a las páginas de la historia la perspectiva de Contreras Torres sobre el episodio del monopolio de la exhibición, sino que también observamos una aplicación sobre la problemática de la crisis industrial suscitada en aquel entonces a la situación del cine mexicano contemporáneo. Así confirma una de las funciones de la disciplina de la Historia, la de estudiar el pasado para establecerlo como un puente reflexivo sobre el presente, en esta ocasión, de la cinematografía. Finalmente, con Bellas de noche y su representación del estado crepuscular y la búsqueda de un renacimiento personal por parte de las vedettes, se extienden las páginas de los estudios sobre el mundo de las estrellas y el espectáculo, fenómeno de interés para investigaciones orientadas a aspectos sociológicos y psicológicos, y sobre sus efectos en la industria cultural. Un factor en común que podemos deducir del trabajo comparativo realizado en el presente artículo es que estas producciones responden, por su utilización de eventos particulares, a lo que Enzo Traverso denominaría una suerte de "turismo de la memoria" (2007, p. 68) al referirse a la tendencia a transformar espacios históricos en lugares de visita o centros de investigación, con sus correspondientes estrategias de publicidad y recepción, que podríamos extender al uso del producto cinematográfico para dicha finalidad. El autor habla de la existencia de una "reificación del pasado que hace de la memoria un objeto de consumo, estetizado, neutralizado y rentable" (2007, p. 68). Este concepto podría ser aplicable a los films analizados si ponemos el foco en el aspecto industrial que 
concierne al cine y que Traverso asocia con "la apropiación de ciertos momentos del pasado por la industria del espectáculo" (2007, p. 68). Conforme a estas consideraciones, estos films nos permiten entender las íntimas conexiones entre la historia y la memoria, ya que al hacer de ellos una especie de historia del cine por medio de los retazos mentales de sus realizadores, nos permiten corroborar la creencia de que la historia, como relato del pasado, nace precisamente de aquella memoria tan marcada por la subjetividad del testigo que la porta, a veces oficializada y otras subterránea, y que esta última necesita de la historia, escrita o audiovisual, como disciplina que reflexione sobre ella.

\section{Referencias bibliográficas}

Arfuch, L. (2007). El espacio biográfico. Dilemas de la subjetividad contemporánea. Buenos Aires: Fondo de Cultura Económica.

Ayala Blanco, J. (1968). La aventura del cine mexicano. México: Era.

Ayala Blanco, J. (1968). El horror. En La aventura del cine mexicano (pp. 209221). México: Era.

Ayala Blanco, J. (1994). Los luchadores muéganos. En La eficacia del cine mexicano. Entre lo viejo y lo nuevo (pp. 157-163). México D.F.: Ed. Grijalbo.

Burke, P. (2005). Visiones de la sociedad. En Visto y no visto. El uso de la imagen como documento histórico (pp. 129-153). Barcelona: Crítica.

Cabañas Osorio, J.A. (2014). La mujer nocturna del cine mexicano. Representación y narrativas corporales, 1931-1954. México: Universidad Iberoamericana.

Castro Ricalde, M. y McKee Irwin, R. (2011). El cine mexicano "se impone". Mercados internacionales y penetración cultural en la época dorada. México D.F.: Universidad Nacional Autónoma de México.

Di Núbila, D. (1959). Historia del cine argentino. Tomo I. Buenos Aires: Cruz de Malta.

Di Núbila, D. (1960). Historia del cine argentino. Tomo II. Buenos Aires: Cruz de Malta.

Di Tella, A. (2008). Yo y Tú: Autobiografía y narración. Archivos de la Filmoteca, $\quad 58, \quad 249-259 . \quad$ Disponible: http://www.archivosdelafilmoteca.com/index.php/archivos/article/view $\angle 196$

Elena, A. (2005). Cruce de destinos: intercambios cinematográficos entre España y América Latina. Madrid: Liceus, Servicios de Gestió.

Ferro, M. (1995). Historia contemporánea y cine. Barcelona: Ariel. 
Flores, S. (2017). Vínculos transnacionales entre México y Estados Unidos: la figura de José U. Calderón en la transición al cine sonoro. Kamchatka. Revista de análisis cultural, 10, 513-531. Disponible: https://ojs.uv.es/index.php/kamchatka/article/view/10821

Flores, S. (2018a). El cine mexicano más allá de las fronteras: aproximación a las actividades de José U. Calderón. Eras. Revista Europeia de Estudos $\begin{array}{llll}\text { Artísticos, } & 9 & \text { (2), } & \text { 20-36. }\end{array}$ http://eras.mundis.pt/index.php/eras/article/view/168

Flores, S. (2018b). El cine que nadie quiso conservar: la memoria familiar y cinematográfica, y nuevas formas de difundir la cultura popular. Imagofagia. Revista de la Asociación Argentina de Estudios y Cine y Audiovisual, 18, 401-416. Disponible: http://asaeca.org/imagofagia/index.php/imagofagia/article/view/1677

Foster, H. (2016). El impulso de archivo. Nimio, 3, 102-125. Disponible: http://papelcosido.fba.unlp.edu.ar/ojs/index.php/nimio/article/view/35 $1 / 586$

García Riera, E. (1963). El cine mexicano. México D.F.: Era.

García Riera, E. (1969). Historia documental del cine mexicano. México D.F.: Era.

Gil Mariño, C. N. y Miranda, L. (2019). Identity mediations in Latin American cinema and beyond. Culture, music and transnational discourses. Newcastle upon Tyne: Cambridge Scholars Publishing.

Gunckel, C. (2015). Mexico on Main Street. Transnational Film Culture in Los Angeles before World Word II. New Brunswick, New Jersey \& London: Rutgers University Press.

Hennebelle, G. y Gumucio Dagrón, A. (1981). Lés cinemas de l’Amérique Latine. Paris: L'Herminier.

King, J. (1994). El carrete mágico. Una historia del cine latinoamericano. Bogotá: Tercer Mundo Editores.

Lefere, R. y Lie, N. (Eds.) (2016). Nuevas perspectivas sobre la transnacionalidad del cine hispánico. Leiden \& Boston: Brill Rodopi.

Levi, G. (2018). Microhistoria e Historia Global. Historia crítica, 69, 21-35.

López, A. (2012). Hollywood, Nuestra América y los Latinos. La Habana: Ediciones Unión.

Lusnich, A.L., Aisemberg, A. y Cuarterolo, A. (Eds.) (2017). Pantallas transnacionales. El cine argentino y mexicano del período clásico. Buenos Aires: Imago Mundi.

Mahieu, J.A. (1966). Breve historia del cine argentino. Buenos Aires: Editorial Universitaria de Buenos Aires.

Martín Barbero, J. (1987). De los medios a las mediaciones. Comunicación, cultura y hegemonía. México: Editorial Gustavo Gili S.A.

Miranda, L. y Rodríguez Riva, L. (Coords.) (2019). Diálogos cinematográficos entre España y Argentina. Volumen 1. Música, estrellas y escenarios compartidos. 1930-1960. Madrid: Shangrilá. 
Moguillansky, M. (2016). Cines del Sur. La integración cinematográfica entre los países del Mercosur. Buenos Aires: Imago Mundi.

Monsiváis, C. (1996). La hora de la máscara protagónica. El Santo contra los escépticos en materia de mitos. En Los rituales del caos (pp. 125-133). México: Ediciones Era.

Morin, E. (1964). Las estrellas del cine. Buenos Aires: Editorial Universitaria de Buenos Aires.

Nichols, B. (1997). La representación de la realidad. Cuestiones y conceptos sobre el documental. Barcelona: Paidós.

Nora, P. (2013). Entre Memoria e Historia. La problemática de los lugares. Módulo virtual: memorias de la violencia. http://www.comisionporlamemoria.org/archivos/jovenesymemoria/bibl iografia_web/historia/Pierre.pdf

Paranaguá, P.A. (1985). O cinema na América Latina. Longe de Deus e perto de Hollywood. Porto Alegre: L \& PM Editores.

Paranaguá, P.A. (2000). Le cinéma en Amérique Latine: le miroir éclaté. Historiographie et comparativisme. Paris: L'Harmattan.

Paranaguá, P.A. (2003). Tradición y modernidad en el cine de América Latina. Madrid: FCE.

Pick, Z. M. (1993). The New Latin American Cinema: a continental project. Austin: University of Texas Press.

Piedras, P. (2014). El cine documental en primera persona. Buenos Aires: Paidós.

Revueltas, J. (1981). Revueltas lanza un Yo acuso: iJenkins estrangula al cine!. En El conocimiento cinematográfico y sus problemas (p. 132-133). México: Era.

Rosenstone, R.A. (1997). El pasado en imágenes. El desafio del cine a nuestra idea de la historia. Barcelona: Editorial Ariel, S.A.

Russo, E. (2017). La cuestión de los archivos: presencia y experiencia en el cine. En A. Rodríguez y C. Elizondo (Comps.), Tiempo archivado: materialidad y espectralidad en el audiovisual (pp. 57-76). Bernal: Universidad Nacional de Quilmes.

Schumann, P. (1987). Historia del cine latinoamericano. Buenos Aires: Legasa.

Serna, L.I. (2014). Making Cinelandia. American Films and Mexican Film Culture before the Golden Age. Durham \& London: Duke University Press.

Sosa, C. (2017). El archivo familiar y el cine expandido. Memoria e identidad en el arte contemporáneo. En A. Rodríguez y C. Elizondo (Comps.), Tiempo archivado: materialidad y espectralidad en el audiovisual (pp. 77-96). Bernal: Universidad Nacional de Quilmes.

Traverso, E. (2007). Historia y memoria. Notas sobre un debate. En M. Franco y F. Levín (Comps.), Historia reciente. Perspectivas y desafíos para un campo en construcción (pp. 67-96). Buenos Aires: Paidós. 
Vázquez Mantecón, A. (2005). Orígenes literarios de un arquetipo fílmico. Adaptaciones cinematográficas a Santa de Federico Gamboa. México: UAM-A.

Viany, A. (1959). Introdução al cinema brasileiro. Rio de Janeiro: Instituto Nacional do Livro-MEC. 